Sergiy Tolstov, Ph.D. in History, associate professor, «The State Institution Institute of World History of NAS of Ukraine», Kyiv, Ukraine.

\title{
STRUCTURAL AND POLITICAL FEATURES OF MULTIPOLARITY
}

Abstract. The main trends in the forging of a multipolar international system are examined in the article. The paper focuses on the overall classification of forms of the system of international relations based on relations of material factors to evaluation of positioning of the leading countries on the international arena. The author reveales as peculiar and distinctive characteristics so some general rules of the implementation of international programs in specific political circumstances in the key periods of world history. The scientific novelty of the research comes from the comprehension of recent events and processes of political change in international relations, world politics that became intense and unexpected.

It is also demonstrated in the article that in the future a polycentric system can take different configurations, and the first evaluation reveals an increasing instability and confrontation in international relations in contemporaneous conditions of forging of the new world order. The development of international processes in that direction has been driven by Russia's aggressive and conscious actions aimed at the destruction of the previous international order established during decades of efforts. Therefore, Russia tried to revise the universally recognized rules and norms in the international community.

In conclusions, the author stresses that the structurally multipolar system of international relations does not necessarily imply a relative equality in the balance of power among the potential major players. The difference in potentials and in common opportunities can be compensated by the ability of certain states to concentrate resources in areas of key priority, and to achieve results through aggressive, unexpected use of power tools or direct threats of using force, through informational and psychological pressure.

Keywords: multipolarity, structure, civilization, balance of power, stability, confrontation.

Вячеслав Ціватий, кандидат історичних наук, доцент, Дипломатична академія України при МЗС України

\section{ЗОВНІШНЯ ПОЛІТИКА І ДИПЛОМАТІЯ США ХХІ СТОЛІТТЯ: ІНСТИТУЦІОНАЛЬНО-КАДРОВИЙ І РЕГІОНАЛЬНИЙ АСПЕКТИ}

Анотація. Стаття присвячена інституціонально-кадровим питанням та етапам становлення дипломатичної служби США, зокрема актуальним питанням моделі ротації дипломатів США та підвищенню їх професійної майстерності. Необхідність кардинальних змін у системі зовнішньополітичних інститутів та доцільність реформування дипломатичної служби США були усвідомлені американською політичною та академічною елітою ще в середині 1990-х років. Події 11 вересня 2001 року слугували каталізатором оновлення моделі підготовки та підвищення кваліфікації дипломатів $i$ моделі кадрового менеджменту в зовнішньополітичній сфері США та актуалізували порушену в дослідженні тему. Дипломатична служба Сполучених Штатів Америки традиційно є відносно невеликою за своєю чисельністю, але одночасно найбільш компетентною, кваліфікованою та ефективною частиною зовнішньополітичного механізму Сполучених Штатів Америки.

Саме досвід США багато в чому є иүінним і корисним для держав пострадянського простору в контексті використання практичного досвіду США, які мають усталені традииї̈ та оперативно й адекватно реагують на нові виклики і загрози глобалізованого 
світу XXI століття в контексті тих реформ дипломатичної служби, щуо розпочалися й в Україні.

Ключові слова: зовнішня політика, дипломатія, інститути дипломатії, інституціоналізачія, Україна, США.

Глобальні зміни в суспільно-політичному житті США, що відбулися після горезвісних подій 11 вересня 2001 р., спонукали політичне керівництво США до пошуку нових шляхів забезпечення національної безпеки в сучасному світі та, відповідно - до кардинального перегляду історично-традиційних підходів до забезпечення кадрової політики у сфері зовнішніх зносин та національної безпеки і оборони, а саме: переходу від традиційної моделі до інноваційної моделі підготовки кадрів та ефективного кадрового менеджменту в дипломатичній службі та оборонній сфері США. Особливу увагу США в сучасних умовах приділяють новаційним підходам щодо порядку здійснення кадрової ротації в Держдепартаменті США i системи підвищення кваліфікації (професійної майстерності та компетентностей) дипломатів, як відповіді на нові виклики i загрози XXI ст.

Необхідність кардинальних змін у системі зовнішньополітичних інститутів та доцільність реформування дипломатичної служби США були усвідомлені американською політичною та академічною елітою ще в середині 1990-х років. Події 11 вересня 2001 р. слугували каталізатором оновлення моделі підготовки та підвищення кваліфікації дипломатів i моделі кадрового менеджменту в зовнішньополітичній сфері США та актуалізували порушену в дослідженні тему.

У XXI столітті особливий інтерес для держав пострадянського простору, у контексті використання практичного досвіду, являє саме досвід США 3 урахуванням тих реформ державної служби, що розпочалися й в Україні та інших державах пострадянського простору в умовах інтеграційних процесів та глобалізації. Адже США мають усталені історичні традиції кадрової політики, оперативно та адекватно реагують на нові виклики й загрози сучасного глобалізованого світу.

Дана стаття продовжує попередні дослідження автора [1, с. 22-25].

Дипломатична служба Сполучених Штатів Америки - традиційно є відносно невеликою за своєю чисельністю, але одночасно найбільш компетентною, кваліфікованою та ефективною частиною зовнішньополітичного механізму Сполучених Штатів Америки. Історично так склалося, що Державний департамент США розташований на відстані кількох кварталів від Білого дому у Вашингтоні в будинку імені Гаррі Трумена. Державний секретар США є головою Державного департаменту США i безпосередньо підпорядковується президентові США. Держсекретар США організовує діяльність і керує департаментом та персоналом. Інституційне затвердження в 1980 р. Закону «Про Закордонну службу США» визначило пріоритети цієї інституції. У Законі зазначено: «Конгрес вважає, що кар'єрна Закордонна служба, заснована на високому професіоналізмі, служить національним інтересам держави i необхідна для здійснення підтримки Президентові й Державному секретареві у ведені ними зовнішніх справ Сполучених Штатів».

У Держдепартаменті є свій власний навчальний центр - Інститут Закордонної служби США. Дипломати і дипломатичні службовці проходять підготовку та 
перепідготовку (підвищення кваліфікації, підвищення майстерності) в Інституті, або в університетах і науково-дослідницьких центрах, як правило, тричі впродовж своєї кар'єри. Підвищення кваліфікації дипломатичних кадрів передбачено Законом 1980 року, в якому зафіксоване так зване правило «три із п'ятнадцяти» згідно з яким кар'єрний дипломат із п’ятнадцяти років своєї роботи не менше трьох років повинен провести у США.

Дипломатична служба США та їі інститути, у відповідь на нові виклики і загрози часу відповідно реформуються й інституціоналізуються. 3 метою своєчасної адаптації до нових умов, зокрема - умов екстремальних, відбувається удосконалення дипломатичного механізму США в контексті перспективних напрямів дипломатичних ініціатив. Теракти 11 вересня 2001 року вплинули на впровадження й посилення безпекової складової в підготовці відповідних дипломатичних кадрів [2, с. 11-16]. Обов'язковими стали спеціальні тренінгові курси щодо моделей поведінки дипломатів у кризових або надзвичайних ситуаціях. Для моделювання умов наближених до реалій у навчальному процесі використовуються спеціальні методики та відповідно - спеціальне технічне та мультимедійне обладнання, спеціальні технічні та імітаційні засоби навчання, тренінгові комплекси.

У відповідь на нові виклики і загрози XXI ст. в Держдепартаменті США особливу увагу акцентували на новаціях щодо порядку здійснення кадрової ротації в Держдепартаменті США [3]. Служба в зовнішньополітичному відомстві США, Державному департаменті, передбачає проведення регулярної кадрової ротації співробітників дипломатичної служби. Порядок проведення ротації регулюється рядом відомчих документів Держдепартаменту, передусім Інструкціями із зовнішньополітичної діяльності (Foreign Affairs Manual). Утім не поодинокі випадки, коли робляться виключення зі стандартного порядку ротації, якщо цього вимагає службова необхідність.

Термін перебування на посаді в апараті Держдепартаменту становить, як правило, два роки. Терміни перебування в закордонному відрядженні залежать як від посади співробітника, так і від країни, в якій цей співробітник працює в закордонній дипломатичній установі (ЗДУ). Стандартний термін перебування молодшого дипломата за кордоном становить два роки. Термін перебування дипломатів середньої та вищої ланок зазвичай становить три роки і більше в країнах 3 нормальними умовами праці, два роки в країнах 3 важкими умовами праці, 3 можливістю подовження відрядження за бажанням співробітника, і не більше одного року в країнах з небезпечними умовами праці. Терміни закордонних відряджень адміністративно-технічного персоналу залежать від контракту i становлять три-п'ять років. При визначенні ступеню умов праці враховується рівень безпеки в країні, кліматичні умови, особливості суспільства та традицій, наявність достатньої інфраструктури для навчання дітей, проведення відпочинку тощо.

Широко використовується так звана «горизонтальна» ротація. Так, після закінчення терміну закордонного відрядження співробітник може бути направлений на роботу в іншу закордонну дипломатичну установу, а не лише в центральний апарат Держдепартаменту. У будь-якому разі після закінчення закордонного відрядження співробітник повинен повернутися до Вашингтона щонайменш на 20 робочих днів для одержання інструкцій. 
Більш того, законодавство США і внутрішні інструкції Держдепартаменту не зобов'язують співробітників працювати в центральному апараті Держдепартаменту в принципі. Дипломат може постійно переходити на нові місця роботи в ЗДУ. Переважна більшість кадрових адміністративно-технічних співробітників Держдепартаменту (specialists) постійно працюють у ЗДУ, не повертаючись до Вашингтона для служби в центральному апараті.

Кадрова ротація зазвичай здійснюється в зимовий та літній періоди. При цьому переважна більшість переїздів припадає саме на літній період. Водночас, із цього правила багато виключень. Якщо цього вимагає ситуація, ротація співробітника може здійснюватись у будь-який час.

Оформленням ротації співробітників опікуються кадрові куратори. Молодшим дипломатам куратори пропонують закордонні відрядження в односторонньому порядку, і від цієї пропозиції небажано відмовлятися. Проте, за неофіційною інформацією, Держдепартамент намагається уникати примусових призначень, i пропозиції оформлюються офіційно вже після попередньої домовленості між співробітником та його куратором. Дипломати середньої та вищої ланок можуть самостійно обирати посади, на які вони хотіли б претендувати, і брати участь у відповідному конкурсі. Такі заявки подаються, як правило, за 12 місяців до планованого призначення. Протягом двох місяців приймається рішення щодо призначення. Якщо дипломат середньої та вищої ланок не пройшов конкурс на обрану посаду, куратор пропонує посаду з числа наявних.

Рішення щодо призначення приймається колегіальним органом в Держдепартаменті. До засідання комісії та прийняття кадрового рішення документи співробітника-кандидата проходять багаторівневе узгодження 3 питань безпеки та професійної відповідності.

Таким чином, у переважній більшості випадків, співробітник знає про наступне місце роботи вже за десять місяців до фактичного переведення. Протягом цих 10 місяців співробітник, паралельно із виконанням поточної роботи, проходить відповідну мовну, культурологічну, політичну, безпекову підготовку в Інституті закордонної служби при Держдепартаменті США (Foreign Service Institute). У разі якщо співробітник знаходиться в ЗДУ, ця підготовка здійснюється дистанційно.

Для роботи у ЗДУ співробітник та його родина, що перебуватиме за кордоном, мають підтвердити належний стан здоров'я та наявність необхідного щеплення. Для цього можна скористатися послугами відомчого медичного закладу Держдепартаменту або звернутися до будь-якого лікаря на свій вибір. Медичний «кліренс» має декілька ступенів. Так, співробітнику може бути заборонено працювати лише в певних країнах чи регіонах.

Зазвичай, під час роботи в ЗДУ зі співробітниками перебувають члени їх родин. Додаткових виплат за перебування членів родин не передбачається, проте на них розповсюджується медичне страхування, дружини та чоловіки співробітників мають переважне право працевлаштування в ЗДУ за тимчасовим контрактом, членам родин забезпечується безкоштовний квиток до США під час відпустки та покриваються витрати на навчання, при чому не тільки шкільне для дітей, але й додаткове для дорослих (наприклад, мовні курси). Якщо співробітник не перебуває в офіційному шлюбі, але має партнера, 3 яким спільно проживає, Держдепартамент у контексті ротації розглядає такого партнера як члена родини. 
Із початку 2007 р. середня тривалість довготермінових відряджень американських дипломатів та адміністративно-технічних працівників становить від одного до трьох років, та обумовлюється рівнем стабільності внутрішньополітичної ситуації та кліматичними умовами країни призначення. Наприклад, термін відрядження до Японії становить три роки, до африканських країн - два роки, до Іраку та Афганістану - один рік.

До 2007 р. тривалість закордонних відряджень становила від одного до чотирьох років але, враховуючи ситуацію зі збільшенням кількості країн 3 нестабільною політичною ситуацією, постало питання щодо прискорення процесу ротації, що призвело до скорочення цього терміну на один рік. Також на один рік скоротився максимальний термін роботи в центральному апараті Державного департаменту між довготерміновими закордонними відрядженнями, який на сьогодні становить п'ять років.

Перспективне планування кадрової ротації в Держдепартаменті США здійснюється на один рік. Як правило, остаточний план ротації на наступний рік затверджується в серпні поточного року. Такий механізм дає можливість пройти відповідну мовну та профільну (професійну) підготовку, сформувати нові або оновити професійні компетенції співробітникам, що направляються в довготермінове відрядження. Професіоналізм і висока фахова підготовка головний лейтмотив моделі підготовки та підвищення кваліфікації дипломатів США до роботи на новому місці призначення. Головний акцент при цьому робиться на знанні країни перебування, особливостях іiї зовнішньої політики, дипломатії, етикету, традицій, культури, економіки, релігії та інших національнокультурних цінностях. Також увага приділяється знанню і розумінню мови країни перебування.

Щодо питання чергування «складних» та «престижних» місць призначення, то воно врегульоване внутрішньою інструкцією Державного департаменту США, яка має назву «Правило справедливого розподілу» (Fair Share Rule). Відповідно до положень цього документа таке чергування є обов'язковим. Існують певні винятки для співробітників, що володіють специфічними мовами, які можуть бути направлені до тієї самої країни.

Слід також зазначити, що відповідно до проекту «Програма кар'єрного росту» (Career Development Program), запровадженого 32005 р., при призначення на посади вищого дипломатичного складу (починаючи 3 радника) однією з умов висувається необхідність попереднього перебування в довготерміновому відрядженні в одній із так званих «складних» країн.

На цей час в Державному департаменті США існує ефективна система заохочень для співробітників, які відряджаються до країн з важкими кліматичними умовами та нестабільною внутрішньополітичною ситуацією, основою якої $\epsilon$ суттєве матеріальне заохочення.

Структура заробітної платні співробітника американського посольства включає суму, аналогічну тій, яку він отримує під час роботи на цій же посаді у Вашингтоні плюс надбавку, яка формується відповідно до кліматичних умов та рівня стабільності внутрішньополітичної ситуації. Наприклад, для співробітника у Женеві це буде $+0 \%$, для співробітника в Мехіко $+15 \%$ (екологічна ситуація), Африка $+35 \%$, максимальною $€$ надбавка, яка сплачується в країнах, де на 
поточний момент відбуваюся бойові дії (найвища надбавка $+70 \%-$ виплачується співробітникам посольства США в Іраку).

Механізм планування та здійснення ротації передбачає, що кожного року протягом червня-липня Держдепартамент розповсюджує серед співробітників список вакантних посад для заповнення в наступному році. Співробітники, які бажають взяти участь у конкурсі (проводиться відповідно до «Правила справедливого розподілу» (Fair Share Rule), заповнюють необхідні документи, в яких вказують короткі відомості про себе та основні причини, чому саме вони мають обіймати запропоновану посаду. Зазначені заявки розглядаються відповідними підрозділами та керівництвом Державного департаменту.

Особливості механізму полягають, з однієї сторони, у транспарентності всього процесу ротації - оскільки інформація про всі наявні посади є доступною всім кандидатам на посаду в закордонній установі, а 3 іншої - у дії «Правила справедливого розподілу» (Fair Share Rule), положення якого хоча й систематично уточнюються, але мають в основі необхідність чергування «складних» та «престижних» місць.

Щодо впливу думки керівника закордонної установи на проведення ротації, то слід зазначити, що на середньому рівні і нижче, формування складу Посольства переважно здійснюється в Державному департаменті, точка зору Посла враховується під час формування так званої «команди», яка складається 3 керівників підрозділів. Зокрема, при призначенні заступників керівника місії Послу на розгляд подаються кандидатури п'яти претендентів на посаду, з яких він обирає кандидатуру.

Щодо імперативності плану ротації та заходів адміністративного впливу на співробітників у разі їх незгоди бути направленими в довготермінове відрядження, слід зазначити наступне.

Ураховуючи існування встановленого максимального терміну (який на сьогодні становить п’ять років) роботи в центральному апараті, у тому випадку, якщо кандидатура співробітника не проходить конкурс на певну посаду, він може спробувати знайти аналогічну посаду в наступному році, або навіть через декілька років. Конкурс здійснюється відповідно до умов «Правил справедливого розподілу» (Fair Share Rule), положення якого передбачають, що в тому випадку, якщо протягом п'яти років співробітник не пройшов конкурс на жодну з посад його буде автоматично направлено в одну 3 країн на вибір керівництва. Це створює передумови для адекватного та реалістичного підходу під час вибору країни, в яку планує бути направлений співробітник. Але за інформацією співробітників Державного департаменту, за часів існування цієї системи (з 1980 р.) випадків такого автоматичного направлення не зафіксовано.

Ураховуючи зазначене, можна дійти висновку, що існуючий метод проведення ротації в Сполучених Штатах є транспарентним механізмом, який забезпечує рівні та справедливі можливості всім співробітникам Державного департаменту щодо участі в конкурсі на заміщення посад у закордонних установах, за умови дотримання законодавства та внутрішніх інструкцій.

Слід зазначити, що існуючий в США механізм ротації безпосередньо пов'язаний із специфікою країни перебування, де для більшості дипломатів привабливішою $є$ робота в Держдепартаменті, аніж за кордоном, а також із сучасною ситуацією у світі, яка вимагає забезпечення постійної присутності 
американських дипломатів у країнах 3 нестабільною внутрішньополітичною ситуацією.

Система підвищення майстерності (кваліфікації) та модель ротації Держдепартаменту США увібрали в себе багатий історичний досвід американської дипломатії, довели на практиці свою функціональність і відповідність реаліям дипломатичної служби США і американського суспільства в цілому. Нормативна база, що регулює кадрові питання Держдепартаменту, постійно удосконалюється і доповнюється новими нормами. Цілком закономірно, що зазначена практика i досвід підготовки дипломатичних кадрів США, принаймні окремі елементи 3 їх досвіду, які впродовж багатьох років довели свою дієвість і ефективність, могли б успішно бути впроваджені й в українській практиці підготовки та підвищення кваліфікації працівників дипломатичної служби [4, с. 117-121; 5; 6].

Таким чином, кажучи про фах дипломата i перспективи розвитку дипломатичної освіти, ми неминуче доходимо висновку щодо нагальної потреби удосконалення існуючих інституціональних моделей підготовки та підвищення кваліфікації дипломатів. Високий професіоналізм і компетентності дипломата в сучасному світі - найважливіша умова реалізації національних інтересів держави.

На виконання першочергових завдань, поставлених керівництвом зовнішньополітичного відомства України щодо реформування дипломатичної служби України, варто врахувати наступне з досвіду США:

1. Розробити науково обгрунтовані базові засади глобальної реструктуризації закордонного та внутрішнього апарату та ії бачення для майбутнього МЗС України, зокрема - основні засади реформування.

2. Кожен дипломат має знати місце роботи після ротації та готуватися до нього через систему підготовки та підвищення кваліфікації працівників дипломатичної служби в Дипломатичній академії України при МЗС України (удосконалювати знання мови країни майбутнього перебування; поглиблювати знання з історії та практики дипломатії, регіоналістики, країнознавства, політики та економіки відповідної галузі).

3. У питанні планування кар'єри важливо перейти на одно-дво-трирічні плани та запровадити середньотермінове планування кар'єри на конкурсних засадах.

4. Професійні дипломати повинні мати юридично гарантовані перспективи кар'єрного зростання.

5. Дипломати мають обов'язково регулярно відвідували країни та регіони, за які відповідають, а тим самим безпосередньо використовувати свої аналітичні здібності та досвід за кордоном більш ефективніше.

6. Необхідно здійснити централізацію інформаційних технологій (IT) i комунікацій, задля гарантування рівного, чіткого та надійного розповсюдження інформації. Мета зазначеного полягає в тому, щоб надати українським дипломатам швидкий доступ до знань та інформації в реальному часі, які вони потребують на своїх робочих місцях або в подорожі.

7. Необхідно впровадити в ДАУ при МЗС України спеціальний тренінг для дипломатів: «Нові навички у вирішенні нових викликів». Оскільки, щоб зустріти виклики трансформаційної дипломатії необхідно реалізувати константу, що дипломати повинні бути різносторонніми, активними, освіченими та мати змогу виконати складні завдання. Трансформаційна дипломатія вимагає, щоб у 
правильних людей були правильні навички в правильному місці в потрібний час. Тривале навчання (система підвищення кваліфікації та набуття нових компетентностей) й програми розвитку кар'єри краще підготують дипломатів i розвинуть їх аналітичні навички.

8. Необхідно оновити навчальні програми і навчальні плани Дипломатичної академії України при МЗС України з метою перефокусування від централізованого внутрішнього центра до закордонних посад i до кожного робочого місця, використовуючи технологію, задля тривалого дистанційного навчання. Локальне навчання та вивчення мови шляхом занурення в подальшому врівноважить досвід аудиторної роботи i більша частина курсу буде пройдена безпосередньо дипломатами за кордоном.

9. Необхідно запровадити ефективну постійно діючу систему тестування дипломатів для кореляції рівня їх підготовки та професійної майстерності через систему підвищення кваліфікації в Дипломатичній академії України при МЗС України.

10. 3 метою кар'єрного зростання і відповідного просування на вищі посади дипломати повинні мати можливість на систематичній основі проходити підвищення кваліфікації та бути експертами принаймні по двох регіонах та володіти не менш, як двома мовами.

11. Дипломати повинні мати відповідну фахову підготовку та змогу ефективно працювати на критичних перетинаннях дипломатичних справ, економічних реконструкцій та воєнних операцій.

Підводячи підсумки вищевикладеного, можна зробити висновок про те, що на початку XXI століття постала проблема створення інноваційної, ефективної системи забезпечення якісного зростання кадрового потенціалу дипломатичної служби США, з урахуванням традицій і тенденцій цивілізаційного поступу, стратегічних напрямів розвитку держави та світового освітнього досвіду. А тому система підготовки кадрів для сфери зовнішніх зносин має зазнати структурної та змістовної трансформації, і першочергово - має бути впроваджена оновлена модель навчання дипломатів - дипломатів XXI століття, 3 урахуванням традиційних та інноваційних методів i засобів удосконалення організації дипломатичних служб провідних держав світу.

Модель підготовки та підвищення професійної майстерності дипломатичних кадрів США підтвердила свою багаторічну дієвість і постійно оновлюється у відповідь на нові виклики й загрози глобалізованого світу XXI століття.

\section{Література}

1.Ціватий В. Г.Пріоритети та принципи кадрового забезпечення дипломатичної служби США: досвід для України / В. Г. Ціватий // Зовнішні справи. - 2013. - № 1. - С. 22-25.

2.Цветков И. А. Дипломатическая служба США после 11 сентября / И. А. Цветков // Современные США: тенденции внутренней и внешней политики. - СПб., 2004. - С. 11-16.

3.Сайт Державного Департаменту США. [Електронний ресурс] - Режим доступу: http://careers.state.gov/officer/index.html - 19.02.2016.

4.Ціватий В. Г. Сучасна дипломатична служба США: традиції, інновації та інституції // В. Г. Ціватий // Сполучені Штати Америки у сучасному світі: політика, економіка, право: Зб. матеріалів Міжнародної науково-практичної конференції. - Львів: DPI, 2014. - C. 117-121.

5.Pigman G. A. Contemporary Diplomacy / G.A. Pigman. - Washington, 2010. - 288 p.

6.Reshaping Defence Diplomacy. - Taylor\&Francis, 2005. - 84 p.

Надійшла до редколегії 29.07.2016 
Viacheslav Tsivatyi, Rector of the Diplomatic Academy of Ukraine, MFA of Ukraine, Ph.D., Associate Professor, Kyiv, Ukraine.

FOREIGN POLICY AND DIPLOMACY OF THE USA OF THE 21st CENTURY: THE INSTITUTIONAL AND PERSONNEL ASPECT

Abstract. The article is dedicated to institutional and human resource issues and stages of becoming the Diplomatic Service of the USA, including current issues rotation model the US diplomats and improve their professional skills.

The need for radical changes in the system of the foreign policy institutions and the advisability of reforming the diplomatic service of the United States were a conscious of the American political and academic elite in the mid-1990s. The events of September 11, 2001 served as a catalyst for renewal model preparation and training of diplomats and personnel management model in the US foreign policy and actualized disturbed in a study the subject. Diplomatic Service of the United States of America traditionally a relatively small in numbers, but also the most competent, qualified and effective part of the foreign policy mechanism for the United States. It is the experience of the United States in many ways is a valuable and useful for the post-Soviet states in the context of the use of the United States experience, having established traditions and promptly and adequately respond to new threats and challenges of the globalized world of the XXI century in the context of the reform of the diplomatic service, which began in Ukraine.

The article covers the urgent issues of the renovation model of diplomats' training in Ukraine on the basis of the analysis of experience of diplomatic service staffing of the USA. The USA experience is particularly important and useful to Ukraine in the context of government service reforms which have begun in Ukraine as well as in other post-soviet states in the frame of integration process and globalization.

Keywords: foreign policy, diplomacy, institutions of diplomacy, Ukraine, the USA.

УДК 32.001 (075.8)

Олег Ткач, доктор політичних наук, професор, Київський національний університет імені Тараса Шевченка, Анатолій Ткач, здобувач, університет «Україна»,

\section{М'ЯКА СИЛА ЯК ІНСТРУМЕНТ НЕПРЯМОГО УПРАВЛІННЯ МІЖНАРОДНИМИ ПРОЦЕСАМИ}

Анотація. В статті розглядається складові концепту м'якої сили в межах реалізації політичними акторами стратегіï smart power. Особливу увагу акцентовано на впливі тлобальних подій на сучасні політичні процеси. Розглядаються складові зовнішньополітичного курсу Сполучених Штатів Америки щуодо краӥн Латинської Америки та Карибського басейну. Особливу увагу акиентовано на впливі глобальних подій на сучасні політичні процеси. У статті аналізується діяльність латиноамериканских держав в боротьбі за перебудову сформованої системи відносин на світовому $i$ регіональному рівнях. міжнародної політики стає «м'яка сила» - комплексний інструментарій вирішення зовнішньополітичних задач з використанням можливостей громадянського суспільства, інформаційно-комунікаційні, гуманітарні та інші альтернативні класичній дипломатії методи і технології. В сучасних умовах «м'яку силу» розглядають у фокусі глобальних соціально-політичних, економічних $i$ культурних процесів. Вони формують нову систему світової політики, в якій класичні ієрархічні 